\title{
Transformations of sulfur compounds in oil shale ash suspension
}

\author{
K. Tamm, R. Kuusik, M. Uibu \& J. Kallas \\ Laboratory of Inorganic Materials, \\ Tallinn University of Technology, Estonia
}

\begin{abstract}
Oil shale (sulfur content $<2 \%$ ) is mainly used for the production of electricity and heat in Estonia. Calcium-rich waste formed in the process of oil shale combustion can be used as sorbents in the $\mathrm{CO}_{2}$ mineralisation process. $\mathrm{CaSO}_{4}$ is the main sulfur compound in the ashes of oil shale, but traces of sulfides are also found. This means that transformations of sulfur compounds in the water environment must be considered while using hydrotransport and open air deposition of oil shale ash as well as treating alkaline ash transportation waters. The transformations of sulfur compounds in model systems (ash - water and CaS - water) were studied in anaerobic and aerobic conditions as well as in the process of aqueous carbonization. The separation of poisonous $\mathrm{H}_{2} \mathrm{~S}(\mathrm{~g})$ was continuously monitored. The results revealed that the leachates of oil shale ash contained mainly sulfates in both aerobic and anaerobic conditions but sulfides and sulfites were also present. Small amount of $\mathrm{H}_{2} \mathrm{~S}(\mathrm{~g})$ was emitted already in the first minutes of carbonation process at high $\mathrm{pH}$ region $(\sim 12)$. The alkalinity decreased during carbonation of ash - water suspensions, triggering substantial $\mathrm{H}_{2} \mathrm{~S}$ release at $\mathrm{pH}<9$ (the content of $\mathrm{H}_{2} \mathrm{~S}(\mathrm{~g}$ ) in off-gas reached to $110 \mathrm{ppm}$ ). Taking environmental issues into consideration, the critical $\mathrm{pH}$ value of the aqueous carbonation system of oil shale ash must be optimized in order to minimize the separation of gaseous $\mathrm{H}_{2} \mathrm{~S}$ emissions.

Keywords: calcium sulfide, oil shale ash, mineral carbonisation, $\mathrm{H}_{2} \mathrm{~S}$.
\end{abstract}

\section{Introduction}

Considering the importance of energetic safety, a local low-calorific fossil fuel oil shale (sulfur content $1-2 \%$ ), is used for heat power production in the 
Republic of Estonia. The oil shale-fired power plants use pulverized firing (PF) as well as circulating fluidized bed combustion (FBC) technologies. The main contaminants are $\mathrm{SO}_{\mathrm{x}}, \mathrm{NO}_{\mathrm{x}}$, particulate matter and $\mathrm{CO}_{2} . \mathrm{PF}$ is related to relatively high $\mathrm{SO}_{2}$ emissions (concentration of $\mathrm{SO}_{2}$ in flue gases is $\sim 2200 \mathrm{mg} / \mathrm{nm}^{3}$ ) [1]. The majority of sulfur emissions pass over the sea, where they deposit as acid and mix with the water upper layers, decreasing the $\mathrm{pH}$ of seawater. The lower part of the sulfur emissions falls on continental soils and fresh waters downwind [2]. FBC eliminates $\mathrm{SO}_{2}$ emissions almost completely; the latter is bound into solid mineral waste - oil shale ash (OSA) [3]. Most of the OSA is deposited in waste piles due to current lack of practical applications and becomes the source of solid, liquid and gaseous pollutants. Various studies have shown that leaching of the minerals and organics from OSA-s is a continuous and relatively long-term process, which means that the ash piles contaminate the environment for a long time [4-6]. $\mathrm{CaSO}_{4}$ is the main sulfur compound present in the oil shale ashes, but also traces of sulfides are found [7,8]. Series of reactions (eqns. (1)-(6)), [5, 8, 9]) occur during ash contact with water and atmospheric components at open-air deposits, including release of gaseous hydrogen sulfide $\left(\mathrm{H}_{2} \mathrm{~S}(\mathrm{~g})\right)[3,9]$ under certain conditions. $\mathrm{H}_{2} \mathrm{~S}(\mathrm{~g})$ is an extremely toxic and irritating gas, which affects the nervous system, intermits breathing or impairs cardiac function. People can smell $\mathrm{H}_{2} \mathrm{~S}$ at low contestations 0.0005 $0.3 \mathrm{ppm}$, the sense of smell is disabled at concentrations $100-200 \mathrm{ppm}$, making it impossible to detect the compound. Rapid death ensues from exposure to more than about $1000 \mathrm{ppm} \mathrm{H}_{2} \mathrm{~S}$ due to asphyxiation [10, 11]. This means that transformations of sulfur compounds in the water environment must be considered while treating ash-water suspensions and ash transportation waters.

Atmospheric emissions of $\mathrm{CO}_{2}$ originating from the Estonian oil shale are also a serious problem. A possible solution to reducing the negative environmental impact of emissions is $\mathrm{CO}_{2}$ mineralization, so-called direct or indirect aqueous carbonation, which leads to abatement of $\mathrm{CO}_{2}$ emissions $\left(\mathrm{CO}_{2}\right.$ binding potential is $200-250 \mathrm{~kg} \mathrm{CO} \mathrm{CO}_{2} / \mathrm{t} \mathrm{OSA}$ ) as well as utilisation of OSA for precipitated calcium carbonate (PCC) production [4, 6, 12-14]. While the carbonation leads to changes of $\mathrm{pH}$ values of suspension the aim of current study was to investigate the transformations of sulfur compounds in the course of leaching (in anaerobic and aerobic environment) and aqueous carbonation of OSA (and $\mathrm{CaS}$ as a model compound) in order to bring out the environmental issues related to possible emissions of toxic $\mathrm{H}_{2} \mathrm{~S}$.

\section{Materials and methods}

In this study two types of model systems (OSA - water and $\mathrm{CaS}$ - water), in anaerobic $\left(\mathrm{N}_{2}\right)$ and aerobic (in air) conditions were investigated. The aim of aerobic conditions was to imitate the situation in the nature in case of open system, and there is air oxygen access to the suspension. The aim of anaerobic conditions was to imitate the same situation without the access of air oxygen, which takes place in the deeper layers of ash piles. CaS- $\mathrm{H}_{2} \mathrm{O}$ systems were used as a model in order to explain and simplify the $\mathrm{CaS}$ transformations taking place 
in OSA-water system. Selected fraction of circulating fluidized bed combustion bottom ash (FBCA) collected from boilers at Estonian power plants was used in the present research. The main characteristics of OSA-s (FBCA and pulverized firing bottom ash (PFA)) [4, 12] including different sulfur forms are presented in table 1. Total sulfur and its bonding forms (sulfide sulfur, sulfate sulfur) in OSA-s were determined according to the Estonian standard EVS 664:1995 for solid fuels [15]. Pure (99.9\%) CaS were supplied by Alfa Aesar (German).

Table 1: $\quad$ The main characteristics of OSA-s.

\begin{tabular}{|c|c|c|c|c|c|c|c|c|c|}
\hline \multirow{2}{*}{$\begin{array}{c}\text { Ash } \\
\text { type }\end{array}$} & \multicolumn{5}{|c|}{ (\% of dry matter) } & $\begin{array}{c}\text { Particle mean } \\
\text { diameter }(\mu \mathrm{m})\end{array}$ & $\begin{array}{c}\text { Density } \\
\left(\mathrm{g} / \mathrm{cm}^{3}\right)\end{array}$ & $\begin{array}{c}\text { BET surface } \\
\text { area }\left(\mathrm{m}^{2} / \mathrm{g}\right)\end{array}$ \\
\cline { 2 - 10 } & $\mathrm{S}_{\text {tot }}$ & $\mathrm{S}_{\text {sulfide }}$ & $\mathrm{S}_{\text {sulfate }}$ & $\mathrm{CaO}_{\text {tot }}$ & $\mathrm{CaO}_{\text {fr }}$ & $\mathrm{CO}_{2}$ & 26.5 & - & 1.76 \\
\hline FBCA & 5.08 & 0.28 & 4.80 & 53.2 & 19.7 & 12.7 & 26.5 & - & 5.26 \\
\hline PFA & 1.17 & 0.05 & 1.12 & 57.2 & 30.0 & 8.3 & 250.0 & 2.83 & 5.0 \\
\hline
\end{tabular}

In this context, there was focused on sulfur compounds, therefore, for further experiments were used FBCA. Equilibrium experiments were carried out in a laboratory-scale batch reactor with volume $800 \mathrm{ml}$ using ash-millipore water suspensions by solid/liquid mass ratio $1 / 10$. CaS suspensions concentrations were as follow (in $\mathrm{g} / \mathrm{L}$ ): $0.13,0.25,0.5,1.5$ and 2.8 . Suspensions were wellmixed at room temperature and atmospheric pressure for $180 \mathrm{~min}$., which was considered sufficient to reach equilibrium. The suspensions were preserved for 24 hours to monitor the behavior of the components for a longer time period. The dynamics of $\mathrm{Ca}^{2+}, \mathrm{OH}^{-}, \mathrm{S}^{2-}, \mathrm{SO}_{4}{ }^{2-}$ and $\mathrm{SO}_{3}{ }^{2-}$-ions was followed during 15-1440 min. Samples were taken with syringe and filtrated $(0.45 \mu \mathrm{m})$. The filtrate was analyzed for $\mathrm{SO}_{4}{ }^{2-}, \mathrm{S}^{2-}, \mathrm{SO}_{3}{ }^{2-}$ (using a Lovibond Spectro Direct spectrophotometer), $\mathrm{Ca}^{2+}$ (titrimetric method ISO 6058:1984) and $\mathrm{OH}^{-}$ (titrimetric method ISO 9963-1:1994 (E)). pH (Mettler Toledo GWb SG2) in the reactor were continuously monitored. Aqueous carbonation was carried out in a $100 \mathrm{ml}$ glass filter absorber using $\mathrm{CO}_{2}$ containing model gas $\left(15 \% \mathrm{CO}_{2}\right.$ in air, which imitates the $\mathrm{CO}_{2}$ concentration in actual flue gases). Gas phase composition $\left(\mathrm{H}_{2} \mathrm{~S}, \mathrm{O}_{2}, \mathrm{CO}_{2}, \mathrm{SO}_{2}\right.$, using flue gas analyzer Testo $\left.350-\mathrm{S} /-\mathrm{XL}\right)$ and suspension $\mathrm{pH}$ were continuously monitored during the experiments. Suspensions were filtered and the solid residue phase was dried at $105^{\circ} \mathrm{C}$. The solid phases were analyzed for chemical composition (free $\mathrm{CaO}$ content (ethyleneglycol method) and $\mathrm{CO}_{2}$ (ISO-10694, ASTM E 191597, DIN EN 13137)).

\section{Results and discussion}

\subsection{Transformations in FBCA - water and CaS - water systems}

\subsubsection{Anaerobic conditions}

Solid CaS dissolves in the water and dissociates (eqn. (1)) to give sulfide ions which will hydrolyze and form hydroxide ions as a result (eqns. (2) and (3)).

$$
\operatorname{CaS}(s) \leftrightarrow \mathrm{Ca}^{2+}(a q)+S^{2-}(a q) \operatorname{CaS}(s) \leftrightarrow \mathrm{Ca}^{2+}(a q)+S^{2-}(a q)
$$


28 Waste Management and the Environment VI

$$
\begin{aligned}
& S^{2-}(a q)+H_{2} O(a q) \leftrightarrow H S^{-}(a q)+O H^{-}(a q) \\
& H S^{-}(a q)+H_{2} O(a q) \leftrightarrow H_{2} S(a q)+O H^{-}(a q)
\end{aligned}
$$

In the anaerobic systems of $\mathrm{CaS}$ - water the liquid phase contains mainly $\mathrm{Ca}^{2+}, \mathrm{HS}^{-}$(main sulfide form in the present $\mathrm{pH}$ [9]), and $\mathrm{OH}^{-}-$ions. When OSA is immersed into water, dissociation of forming portlandite $\left(\mathrm{CaOH}_{2}\right)$, eqn. (8) and dissolution of different salts (anhydrite, gypsum, calcite, dolomite, periclase) occur [14]. During the first minutes of $\mathrm{CaS}$ - water and FBCA - water contact, the solution becomes deeply alkaline ( 11.4 and $\sim 12.7$, accordingly) and the $\mathrm{pH}$ stabilizes at these values, fig. 1 . The equilibrium is reached more rapidly in case of $\mathrm{FBCA}-\mathrm{H}_{2} \mathrm{O}$ system. The $\mathrm{pH}$ of aqueous suspensions falls only a few units under anaerobic conditions. This is due to oxidation of sulfide ions, eqns. (4), (5) and (6) or the $\mathrm{H}_{2} \mathrm{~S}$ evaporation into the gas phase, eqn. (7).

$$
\begin{gathered}
H S^{-}(a q)+1.5 O_{2}(a q) \leftrightarrow S O_{3}^{2-}(a q)+H^{+}(a q) \\
S O_{3}^{2-}(a q)+0.5 O_{2}(a q) \leftrightarrow S O_{4}^{2-}(a q) \\
S O_{3}^{2-}(a q)+0.5 O_{2} H S^{-}(a q) \leftrightarrow S_{2} O_{3}^{2-}(a q)+O H^{-}(a q) \\
H_{2} S(a q) \leftrightarrow H_{2} S(g)
\end{gathered}
$$

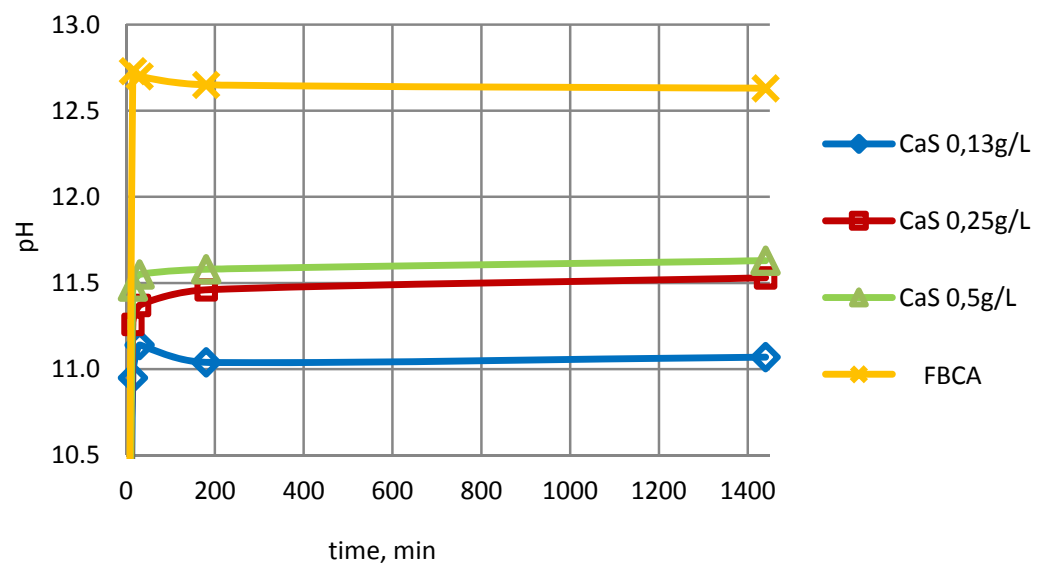

Figure 1: Changes in the $\mathrm{pH}$ in $\mathrm{CaS}-\mathrm{H}_{2} \mathrm{O}$ and $\mathrm{FBCA}-\mathrm{H}_{2} \mathrm{O}$ systems under anaerobic conditions.

The oxidation of sulfides promotes $\mathrm{pH}$ decrease in the system, as the sulphates are weaker bases than the sulfides. Until there is sufficient amount of solid phase, the oxidation of sulfides does not affect the $\mathrm{pH}$ of the solution, as oxidized ions are replaced by the dissociation of $\mathrm{CaS}$. The greater amount of initial $\mathrm{CaS}$ added into the water the greater the concentration of sulfides in the liquid phase. In contrast to aqueous suspensions of $\mathrm{CaS}$ the concentration of $\mathrm{S}^{2-}$ ions in aqueous phase kept growing continuously in case of FBCA. Sulfide ion 
diffusion from the solid FBCA particle was slower and the equilibrium was not achieved within 24 hours, fig. 2 . The content of sulphate ions in the liquid phase increased rapidly $>1000 \mathrm{mg} / \mathrm{L}$ in case of FBCA - water system and stabilized after 3 hours (180 minutes). In case of the CaS suspensions the content $\mathrm{SO}_{4}{ }^{2-}$ ions increased steadily from 2 to $23 \mathrm{mg} / \mathrm{L}(\mathrm{CaS} 0.5 \mathrm{~g} / \mathrm{L})$ during 24 hours, fig. 3 due to leakages in the air-tight system, thus promoting the formation of sulfates. Sulfites content in FBCA leachates was lower compared to $\mathrm{CaS}$, fig 4. Sulfites were probably formed during the analysis.

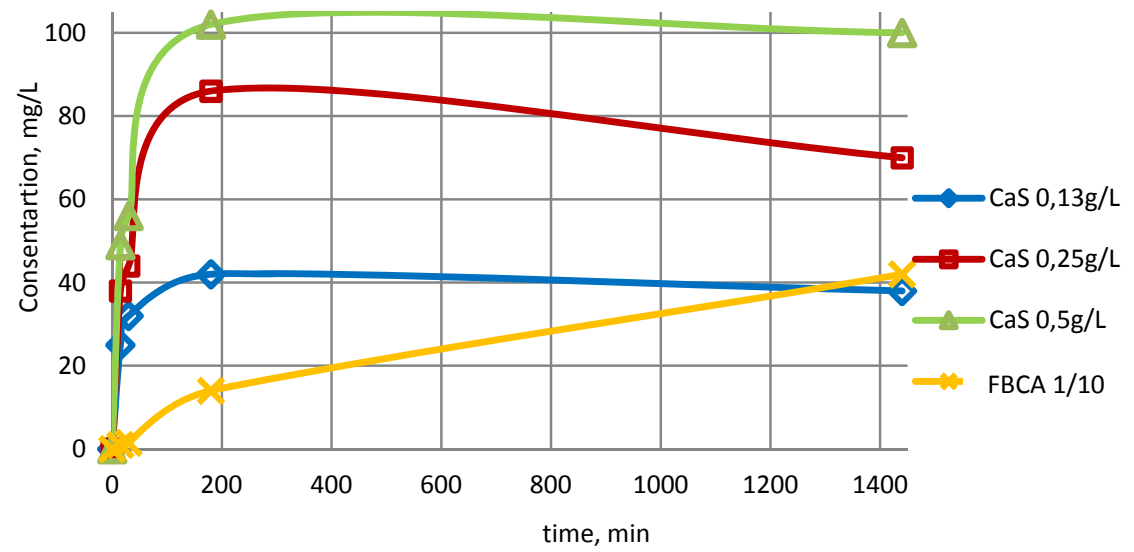

Figure 2: Changes in $\mathrm{S}^{2-}$-ion concentration in $\mathrm{CaS}-\mathrm{H}_{2} \mathrm{O}$ and $\mathrm{FBCA}-\mathrm{H}_{2} \mathrm{O}$ systems under anaerobic conditions.

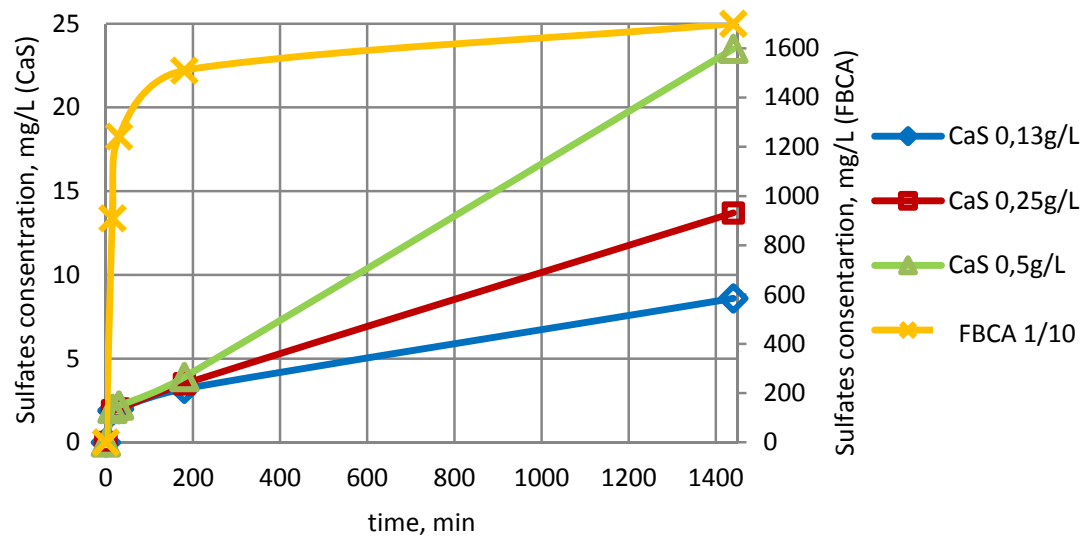

Figure 3: Changes in $\mathrm{SO}_{4}{ }^{2-}$-ion concentration in $\mathrm{CaS}-\mathrm{H}_{2} \mathrm{O}$ and $\mathrm{FBCA}-\mathrm{H}_{2} \mathrm{O}$ systems under anaerobic conditions. 


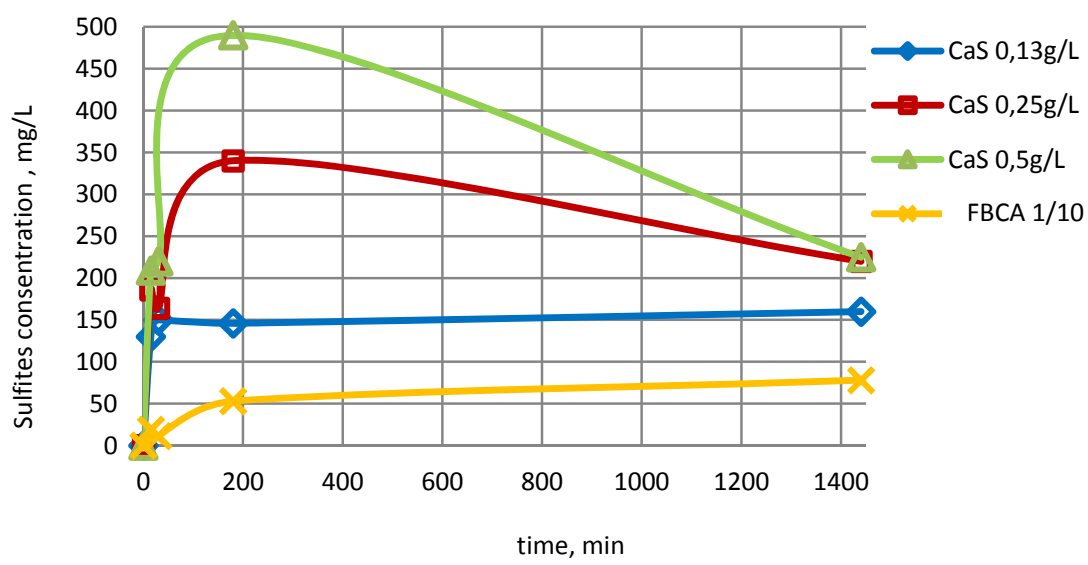

Figure 4: Changes in $\mathrm{SO}_{3}{ }^{2-}$-ion concentration in $\mathrm{CaS}-\mathrm{H}_{2} \mathrm{O}$ and $\mathrm{FBCA}-\mathrm{H}_{2} \mathrm{O}$ systems under anaerobic conditions.

\subsubsection{Aerobic conditions}

After dissociation of $\mathrm{CaS}$ the resulting sulfides bound protons in water so rapidly that the oxidation of solid phase is almost non-existent [9]. The results showed that the majority of sulfides oxidized to sulfites, and reduced sulfates. The aqueous suspensions could include polysulfides and thiosulfates which were not determined in this study; the latter may affects the results. In aerobic conditions the $\mathrm{pH}$ of the ash leachates increased higher more rapidly as compared CaSwater systems, fig. 5 .

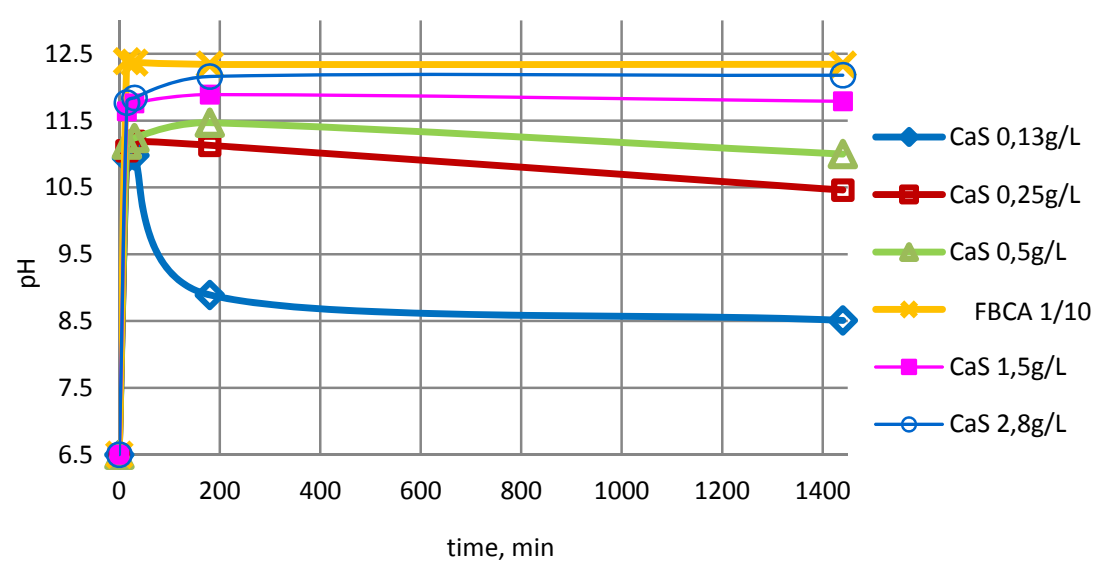

Figure 5: Changes in the $\mathrm{pH}$ in $\mathrm{CaS}-\mathrm{H}_{2} \mathrm{O}$ and $\mathrm{FBCA}-\mathrm{H}_{2} \mathrm{O}$ systems under aerobic conditions. 
Thus, the formation of $\mathrm{Ca}$ and $\mathrm{Mg}$ hydroxides as well as dissolution, eqn. (8) and (9) was faster than the dissociation of $\mathrm{CaS}$ to cations and anions, eqn. (1), and following reaction between sulfides and protons, eqn. (2) and (3).

$$
\begin{gathered}
\mathrm{CaO}(s)+\mathrm{H}_{2} \mathrm{O}(a q) \leftrightarrow \mathrm{Ca}(\mathrm{OH})_{2}(s) \leftrightarrow \mathrm{Ca}^{2+}(a q)+2 \mathrm{OH}^{-}(a q) \\
\mathrm{MgO}(s)+\mathrm{H}_{2} \mathrm{O}(a q) \leftrightarrow \mathrm{Mg}(\mathrm{OH})_{2}(s) \leftrightarrow \mathrm{Mg}^{2+}(a q)+2 \mathrm{OH}^{-}(a q)
\end{gathered}
$$

In case of lower $\mathrm{CaS}$ concentrations $(\mathrm{CaS}<1.5 \mathrm{~g} / \mathrm{L})$ the dissociation of $\mathrm{CaS}$ was complete, during the 30 minute of $\mathrm{CaS}$ - water contact, so desorption and oxidation of sulfides could not be replaced on account of solid $\mathrm{CaS}$ and the system`s $\mathrm{pH}$ decreases due to absorption $\mathrm{O}_{2}$ and $\mathrm{CO}_{2}$. At higher concentrations $(\mathrm{CaS}>1.5 \mathrm{~g} / \mathrm{L})$ the system reaches equilibrium and subsequent processes are slow. In FBCA - water system, within 24 hours, the concentration of $\mathrm{S}^{2-}, \mathrm{SO}_{4}{ }^{2-}$ and $\mathrm{SO}_{3}{ }^{2-}$-ions increase steadily, fig. 6,7 and 8 . Thus, after 24 hours of leaching the source of sulfides still remains. Days after, at lower concentrations $(\mathrm{CaS}<0.5 \mathrm{~g} / \mathrm{L})$, the equilibrium was achieved and sulfites are partially oxidized to sulfates, fig. 7 and 8. Diffusion of sulfides from the ash particle into solution took much more time as compared to pure $\mathrm{CaS}$. In $\mathrm{FBCA}-\mathrm{H}_{2} \mathrm{O}$ system the sulfates had already reached equilibrium after 3 rd hour of leaching, as in case of CaS$\mathrm{H}_{2} \mathrm{O}$ systems the concentration of sulfates in the liquid phase kept increasing, fig. 7. Diffusion of sulfates from ash was faster than the oxidation of sulfides to sulfates. Fewer sulfides formed into FBCA $-\mathrm{H}_{2} \mathrm{O}$ system than into $\mathrm{CaS}-\mathrm{H}_{2} \mathrm{O}$ system. Similarly to sulfides (fig. 6), due to oxidation of the latter, the content sulfites increases, fig. 8. Share of sulfites transform to sulfates, depending on the diffusion of sulfides into liquid phase.

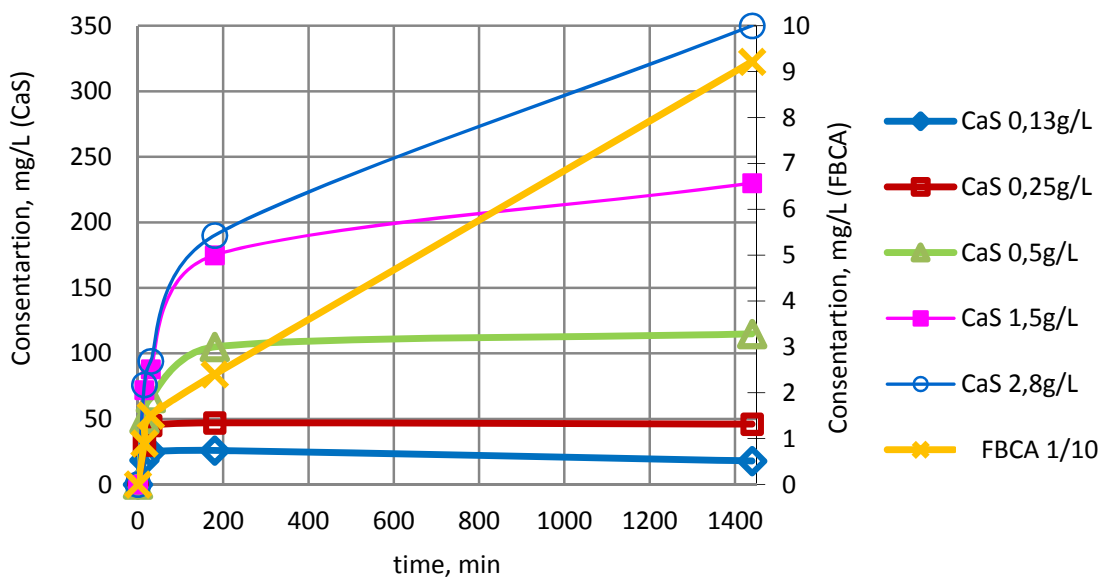

Figure 6: Changes in $\mathrm{S}^{2-}$-ion concentration in $\mathrm{CaS}-\mathrm{H}_{2} \mathrm{O}$ and $\mathrm{FBCA}-\mathrm{H}_{2} \mathrm{O}$ systems under aerobic conditions. 


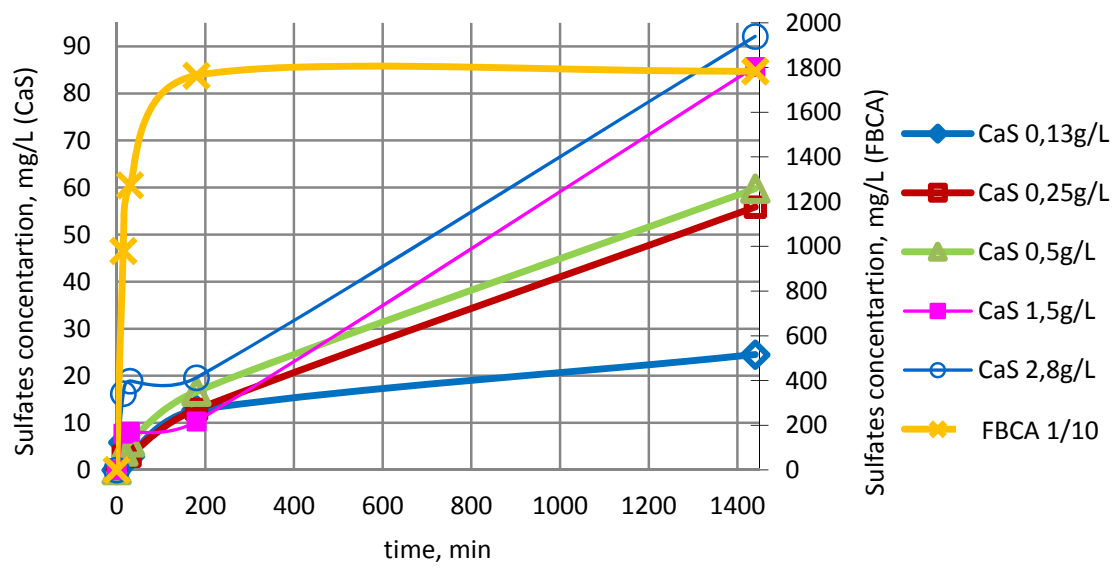

Figure 7: Changes in $\mathrm{SO}_{4}{ }^{2-}$-ion concentration in $\mathrm{CaS}-\mathrm{H}_{2} \mathrm{O}$ and $\mathrm{FBCA}-\mathrm{H}_{2} \mathrm{O}$ systems under aerobic conditions.

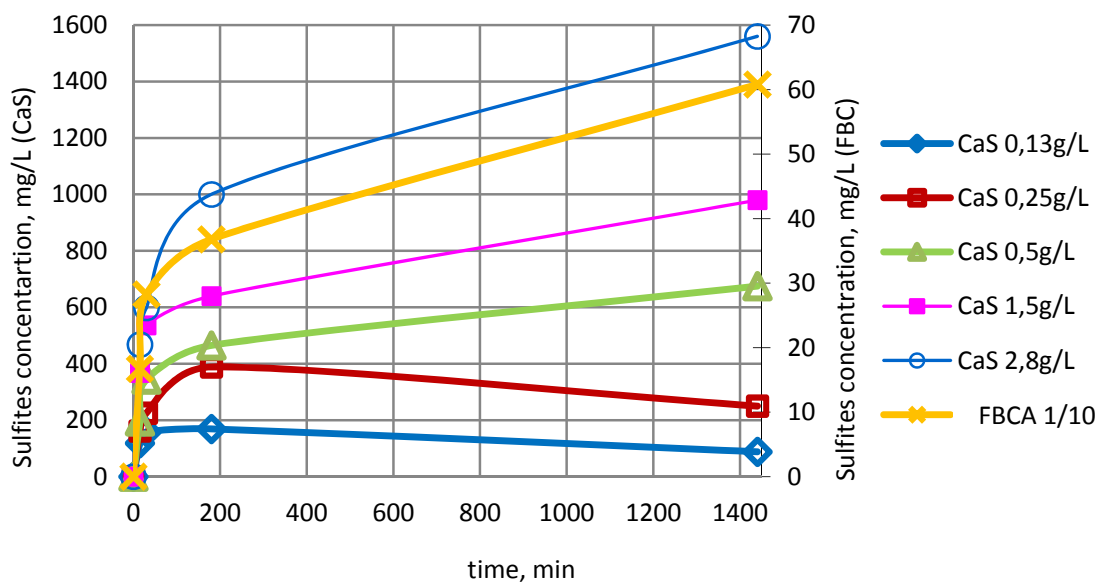

Figure 8: Changes in $\mathrm{SO}_{3}{ }^{2-}$-ion concentration in $\mathrm{CaS}-\mathrm{H}_{2} \mathrm{O}$ and $\mathrm{FBC}-\mathrm{H}_{2} \mathrm{O}$ systems under aerobic conditions.

\subsubsection{Comparison of the results in anaerobic and aerobic conditions}

In both aerobic and anaerobic conditions the aqueous solutions became rapidly highly alkaline after the contact of ash and water, the $\mathrm{pH}$ remained stable upon the arrival of the equilibrium, fig. 1 and fig. 5. Thus, proton capture of sulfides, releasing $\mathrm{OH}^{-}$-ions into solution, eqn. (2) and (3), is preferred as compared to the oxidation of sulfides, eqn. (4-6).

In aerobic conditions $(\mathrm{CaS}<1.5 \mathrm{~g} / \mathrm{L})$ than equilibrium, $\mathrm{pH}$ of the solution falls within 24 hours. Under anaerobic condition at higher $\mathrm{CaS}$ concentrations $(\mathrm{CaS}>0.13 \mathrm{~g} / \mathrm{L})$ the suspension liquid phase contained $\sim$ twice as much $\mathrm{OH}^{-}$-ions 
( $\sim 4 \mathrm{mmol} / \mathrm{L})$ as compared to $\mathrm{Ca}^{2+}$-ions $(\sim 2 \mathrm{mmol} / \mathrm{L})$, as result of $\mathrm{H}_{2} \mathrm{~S}$ in the solution which leads to the additional metallic sulfide dissolution according to eqn. (11):

$$
H_{2} S(a q)+S^{-}(a q) \leftrightarrow 2 H S^{-}(a q)
$$

Therefore, more hydrogen sulfide ions would be provided into solution and for equilibrium constants to remain the hydrogen sulfide ions have to bind more protons, resulting formation of $\mathrm{H}_{2} \mathrm{~S}$ and remaining of more hydrogen ions in the solution. In case of anaerobic conditions the sulfides content in the liquid phase was lower, fig. 2, 5. Thus, the oxidation of sulfur compounds accelerates the dissolution of $\mathrm{CaS}$. Although $\mathrm{H}_{2} \mathrm{~S}$ releasing in gaseous form has an important role in solid phase dissociation, the slower dissociation of $\mathrm{CaS}$ was determined in anaerobic conditions. Desorption of $\mathrm{H}_{2} \mathrm{~S}$ was suppressed in the presence of oxidants. Under aerobic conditions $\mathrm{Ca}^{2+}$-ions content decreased, table 2, thus in oxidizing condition due to binding of the $\mathrm{Ca}^{2+}$-ions (eqn. (8) and (13)), the solidification was beneficiary. Therefore contrary to the sulfides, the concentration of $\mathrm{SO}_{4}{ }^{2-}$-ions was in every case higher under aerobic conditions fig. 3 and 7.

\subsection{Aqueous carbonation of FBCA and CaS}

Carbonation experiments showed that small amounts of $\mathrm{H}_{2} \mathrm{~S}$ were emitted already in the region of high $\mathrm{pH}$ value $(\mathrm{pH} 12)$ during the first minutes of carbonation process, fig. 9. The system $\mathrm{pH}$ decreases as model gas was bubbled through the aqueous suspensions of FBCA or $\mathrm{CaS}$. $\mathrm{CO}_{2}$ behaves as acid in the aqueous systems [14], eqn. (12):

$$
\begin{aligned}
\mathrm{CO}_{2}(g)+\mathrm{H}_{2} \mathrm{O}(a q) \leftrightarrow \mathrm{H}_{2} \mathrm{CO}_{3}(a q) & \leftrightarrow \mathrm{H}^{+}(a q)+\mathrm{HCO}_{3}^{-}(a q) \\
\mathrm{Ca}^{2+}(a q)+\mathrm{CO}_{3}^{2-}(a q) & \leftrightarrow \mathrm{CaCO}_{3}(s)
\end{aligned}
$$

During carbonation, in case of $\mathrm{CaS}-\mathrm{H}_{2} \mathrm{O}$ system, $\mathrm{pH}$ decreases faster and to lower values, than in $\mathrm{FBCA}-\mathrm{H}_{2} \mathrm{O}$ system, fig. 9. In case of $\mathrm{CaS}$ the $\mathrm{pH}$ reached equilibrium ( $\mathrm{pH}$ 6.3) in 5 minutes, as in case of FBCA system in 30 minutes ( $\mathrm{pH}$ 6.8). In FBCA system $\mathrm{pH}$ stayed on a high level until almost all free lime $(\mathrm{CaO})$ was utilized (as long as calcium was carbonated). In $\mathrm{CaS}-\mathrm{H}_{2} \mathrm{O}$ system the $\mathrm{pH}$ decreased rapidly because of lack of $\mathrm{CaO}$. $\mathrm{pH}$ decrease favors the evaporation of $\mathrm{H}_{2} \mathrm{~S}$, which also earlier studies refer [14]. When the suspension $\mathrm{pH}$ decreased below 7.5, the content of $\mathrm{H}_{2} \mathrm{~S}$ in off-gas reached $110 \mathrm{ppm}$ in case of FBCA and $>1500 \mathrm{ppm}$ in case of $\mathrm{CaS}(\mathrm{CaS} 0.6 \mathrm{~g} / \mathrm{L})$. Release of the $\mathrm{H}_{2} \mathrm{~S}$ stopped in correlation with the respective source of sulfide. Thus, at $\mathrm{pH}$ values $<10$ desorption of gaseous $\mathrm{H}_{2} \mathrm{~S}$ is preferred to oxidation of sulfides, which was expressed by the intense emission of $\mathrm{H}_{2} \mathrm{~S}$. Determination of solid phase composition indicated that over $85 \%$ of free lime (content of free $\mathrm{CaO}<2 \%$ ) was utilized before reaching into the intensive $\mathrm{H}_{2} \mathrm{~S}_{\mathrm{g}}$ emission region $(\mathrm{pH}<9)$ during aqueous carbonation of OSA. The amount of $\mathrm{CO}_{2}$ bound was $210 \mathrm{~kg} \mathrm{CO} \mathrm{CO}_{2} / \mathrm{t}$ FBCA. 


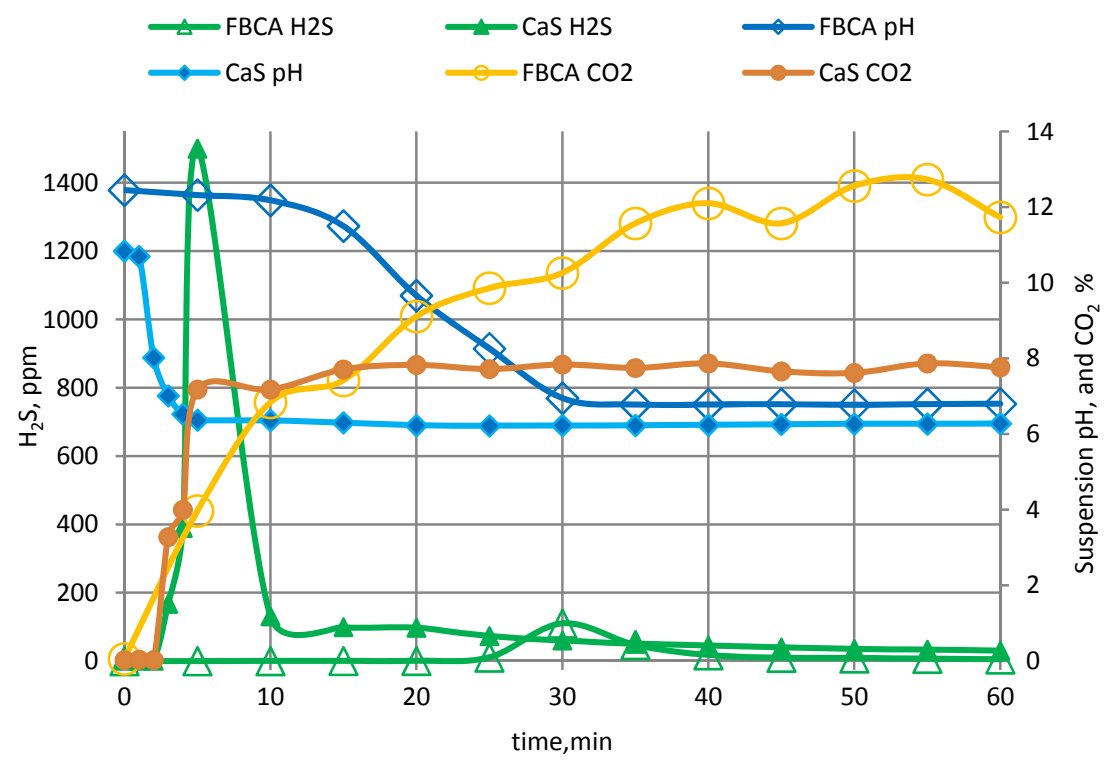

Figure 9: Changes in the composition of off-gas and suspension $\mathrm{pH}$ during aqueous carbonation of FBCA.

\section{Conclusions}

Experiments in model systems showed that transformations of the sulfur compounds in the water environment must be considered while using hydrotransport and open air deposition of oil shale ash as well as treating alkaline ash transportation waters. $\mathrm{H}_{2} \mathrm{~S}$ has an important role in $\mathrm{CaS}$ dissociation. As long as there is a solid $\mathrm{CaS}$ in the system, the source of sulfides, $\mathrm{O}_{2}$ and $\mathrm{CO}_{2}$ absorption does not affect the oxidation of sulfides and suspensions $\mathrm{pH}$ decrease The kinetic desorption of gaseous $\mathrm{H}_{2} \mathrm{~S}(\mathrm{~g})$ is preferred to oxidation of sulfides when suspension $\mathrm{pH}<10$. Taking environmental problems into consideration, the $\mathrm{pH}$ of the aqueous carbonation system of OSA must be monitored - the separation of highly toxic gaseous $\mathrm{H}_{2} \mathrm{~S}(\mathrm{~g})$ can be minimized by optimizing $\mathrm{pH}$ value of the system. Carbonation should be discontinued at the time when no more $\mathrm{CO}_{2}$ is committed by the amount of free $\mathrm{CaO}$ in the OSA, thus preventing a rapid $\mathrm{pH}$ decrease of the system.

\section{Acknowledgements}

The financial support of Estonian Ministry of Education and Research (SF0140082s08), Estonian Science Foundation (Grant 9334) and Graduate School "Functional materials and technologies" is gratefully acknowledged. 


\section{References}

[1] A. Ots, Oil Shale Fuel Combustion. Tallinn: Tallinn University of Technology Press, 2006.

[2] Rappold, T.A. and Lackner, K. S., Large scale disposal of waste sulfur: From sulfide fuels to sulfate sequestration. Energy, 35(3), pp. 1368-1380, 2010.

[3] Anthony E.J., Jia L., Iribarne, A.P., Welford, G., Wang, J. and Trass, O., Calcium sulphide in FBC boilers and its fate using liquid water reactivation. Fuel, 85(12-13), pp. 1871-1879, 2006.

[4] Velts, O., Uibu, M., Rudjak, I., Kallas, J. and Kuusik, R., Utilization of oil shale ash to prepare PCC: leachibility dynamics and equilibrium in the ashwater system. Energy Procedia, 1(1), pp. 4843-4850, 2009.

[5] Mõtlep R., Sild T., Puura E. and Kirsimäe K., Composition, diagenetic transformation and alkalinity potential. Journal of Hazardous Materials, 184(1-3), pp. 567-573, 2010.

[6] Velts, O., Hautaniemi, M., Kallas, J., Kuosa, M. and Kuusik, R., Modeling calcium dissolution from oil shale ash: Part 2. Continuous washing of the ash layer. Fuel Processing Technology, 91(5), 491-495, 2010.

[7] Kuusik, R., Uibu, M., and Kirsimäe, K., Characterization of oil shale ashes formed at industrial-scale CFBC boilers. Oil Shale, 22(4), pp. 407-419, 2005.

[8] Mölder, L., Elenurm, A. and Tamvelius, H., Transformation of Sulphur Compounds in a Hydraulic Ash-Discharge Unit. Proc. Estonian Acad. Sci. Chem., 47(1), pp. 3-10, 1998.

[9] Carcia-Calzada, M., Marbán, G. and Fuertes, A.B., Decomposition of CaS Particles at Ambient Conditions. Chemical Engineering Science, 55(9), pp. 1661-1674, 2000.

[10] Roth, S., and Goodwin, V., (eds). Health Effects of Hydrogen Sulphide: Knowledge Gaps, Alberta Environment: Edmonton, 1999.

[11] Manahan S. E., (eds). Environmental Chemistry, Ninth Edition, Boca Raton: CRC press, 2010.

[12] Velts, O., Hautaniemi, M., Kallas, J. and Kuusik, R., Modelling calcium dissolution from oil shale ash: Part 1. Ca dissolution during ash washing in a batch reactor. Fuel Processing Technology, 91(5), pp. 486-490, 2010.

[13] Uibu, M., Velts, O. and Kuusik, R., Developments in $\mathrm{CO}_{2}$ mineral carbonation of oil shale ash. Journal of hazardous materials, 174(1-3), pp. 209-214, 2010.

[14] Uibu, M., Velts, O. and Kuusik, Aqueous carbonation of oil shale wastes from Estonian power production for $\mathrm{CO}_{2}$ fixation and PCC production. Proc. Of the Conf. of Young Scientist on Energy Issues, pp. 415-42, 2011.

[15] EVS 664:1995. Solid fuels sulfur content. Determination of total sulfur and its bonding forms. Estonian Centre for Standardisation, Tallinn. http://www.evs.ee/products/evs-664-1995 